\title{
Uniwersytet i komercjalizacja. Rekonstrukcja zachodniej debaty
}

\author{
KEY WORDS \\ commercialization of \\ the modern university, \\ marketization of \\ academic knowledge, \\ "supermarketization"
}

\begin{abstract}
Melosik Zbyszko, Uniwersytet i komercjalizacja. Rekonstrukcja zachodniej debaty [University and Commercialization. Reconstruction of the Western Debate]. Kultura - Społeczeństwo - Edukacja nr 1, 2012, Poznań 2012, pp. 21-33, Adam Mickiewicz University Press. ISBN 978-83-232-2470-9

The article concerns the phenomenon of commercialization of the modern university, and especially its two primary functions: research and teaching. On one hand, the author analyzes such phenomena as the marketisation of academic knowledge, which becomes a "commodity for sale", and scientists, because of the dependence of the big bussines are forced to give up their passion for seeking truth. On the other hand, the learning process is shown in the context of the prevailing reductionist phenomenon of "supermarketization", where the student becomes the client and the university is transformed into a big department store.
\end{abstract}

W przeszłości oskarżano często uniwersytety (i profesorów) o swoisty „separatyzm” - tworzenie różnorodnych „barier” utrudniających integrację z "resztą społeczeństwa”. Uniwersytet zdawał się być „wieżą z kości słoniowej”, majestatycznym symbolem Prawdy i Wiedzy (a często i moralności), znajdującym się poza (ponad?) społeczeństwem. Wstęp do tej krainy Mędrców i Ekspertów, niezależnej i rządzącej się własnymi prawami, był dla „zwykłych śmiertelników” niemal niemożliwy (aby się w niej znaleźć, musieli przejść przez trudne inicjacje i wielokrotnie potwierdzać swoje predyspozycje intelektualne i osobowościowe).

Współcześnie sytuacja zmieniła się radykalnie. Uniwersytet staje się jedynie jedną z wielu instytucji społecznych, a jego działania postrzegane są w kategoriach dostarczania „usług” i „produktów”. Co prawda akademicy żyją jeszcze złudzeniami co do swojej społecznej „wyjątkowości”, lecz rozwiewane są one w sposób brutalny poprzez oczywiste, coraz głębsze uzależnienie uniwersytetów i profesorów od środków finansowych pochodzących od wielkich firm; w konsekwencji - jak to 
obrazowo ujmuje P.B. Altbach - „«Złoty wiek» profesji, związany z instytucjonalną ekspansją, znaczącą autonomią, dostępnością środków na badania, coraz większym prestiżem i pensją [...], ma się ku końcowi" (Altbach, 1997: 315). Badania akademickie prowadzi się w coraz większym stopniu „na zamówienie”, a „kohorty absolwentów" są produkowane zgodnie z potrzebami rynku pracy (który wyznacza też pożądane cechy tożsamości absolwenta). Z drugiej strony, rządy państw postrzegają edukację akademicką niemal wyłącznie poprzez pryzmat jej potencjalnego wkładu w rozwój ekonomiczny danego kraju - w kontekście współzawodnictwa na "globalnym rynku”.

Wymagania stawiane przez rządy placówkom edukacji wyższej są proste i opierają się na paradygmacie „przydatności”: idea „wiedzy dla wiedzy” ustąpiła idei „wiedzy użytecznej”. Z kolei idea mądrego, światłego absolwenta-intelektualisty została zastąpiona przez model absolwenta-,,wyspecjalizowanego pragmatyka”, który z łatwością znajdzie pracę i będzie przyczyniał się do ekonomicznej „prosperity" (sam na tym korzystając). Absolwent taki jest - jak pesymistycznie pisze Osmo Kivinen - „całkowicie skomodyfikowany”. I tak wielkie korporacje oczekują, że jako „siła robocza” będzie on „wysoko wyspecjalizowanym ekspertem”, wyposażonym w możliwą do łatwego zweryfikowania i odpowiadającą potrzebom pracodawców wiedzę i kwalifikacje, ma przy tym posiadać zdolność „rozumienia mechanizmów rynkowych”, zasadniczą jego cechą ma być też „plastyczność" - umiejętność adaptacji do zmieniających się warunków, a w szczególności do nowych technik i technologii. Z kolei z perspektywy państwa absolwent - postrzegany jako „ludzki kapitał” - powinien, jak już wspomniano, wnosić wkład do „konkurencyjności" na globalnych światowych rynkach i przyczyniać się do zaspokajania potrzeb społeczeństwa (Kivinen, Ahola, 1999: 205; Kivinen, 1997: 446).

Komercjalizację absolwentów można więc rozpatrywać przynajmniej w trzech aspektach. Po pierwsze, występuje ich komercjalizacja jako grupy: dostarczani są w gotowych „paczkach” czy „pakietach” na rynek. Po drugie, występuje komercjalizacja ich tożsamości: pragną zdobyć głównie wiedzę i kompetencje, które pozwolą im odnaleźć się za wszelką cenę na rynku pracy. Z punktu widzenia ekonomii ważne jest przy tym, aby absolwent był „wydajny” $i$ „nie robił problemów”. Po trzecie (co wynika z poprzednich dwóch aspektów oraz ogólnej logiki rozwoju współczesnego społeczeństwa), większość absolwentów jest zorientowana na „mieć” (a nie na "być"), dąży do nieograniczonej konsumpcji, nie poszukuje sensu życia ani nie pragnie rozwijać krytycznego myślenia wobec rzeczywistości (por. Melosik, 2000: 91-94). Oczekują oni także szybkiego i bezproblemowego sukcesu, choć nie jest on gwarantowany. Oto bowiem rynek pracy, na który wchodzą absolwenci

1 Polski kontekst tego problemu omówiony jest przez Z. Kwiecińskiego w: Tropy - ślady próby. Szkice z pedagogiki pogranicza, Poznań-Olsztyn 2000, s. 126-133. 
z dyplomami, okazuje się być często - aby użyć sformułowania Z. Kwiecińskiego - „rynkiem pozorów”, oferującym (nieracjonalną) „nadzieję na dobrą lub lepszą pracę i jakość życia, pozycję społeczną", w praktyce jednak istnieje niewielka szansa na urzeczywistnienie „wielkiej kariery” (Kwieciński, 2000: 103).

Na przestrzeni ostatnich dekad wystąpiło więc zjawisko zasadniczego „przesunięcia" w zakresie społecznych wartości, które stanowią punkt wyjścia postrzegania uniwersytetów: o ile jeszcze w niedawnej przeszłości edukacja wyższa postrzegana była jako wartość „sama w sobie”, a jej celem był rozwój jednostki i długoterminowe korzyści społeczne, to dzisiaj - jak pisze Malcolm Tigh - „poszukuje się natychmiastowych, bezpośrednich i możliwych do zastosowania zysków od inwestycji w nauczanie czy badania" (Tight, 1988: 117). Edukacja wyższa przekształcona więc została - zdaniem Patricii J. Gumport - z ,instytucji społecznej” w „instytucję ekonomiczną”. W tym pierwszym przypadku celem uniwersytetu była „kontynuacja historii i tradycji", eksponowano przy tym jego socjalizacyjną funkcję (a to przez kształtowanie osobowości jednostek, szczególnie postaw obywatelskich, rozwijanie orientacji na zdobywanie wiedzy oraz umiejętności rozróżniania między „dobrem” a „złem”, tym co jest „wartościowe”, a tym, co „wartości nie posiada” itd.). Z kolei w dominującym współcześnie modelu uniwersytetu jako „instytucji ekonomicznej" postrzega się go przez pryzmat jego wkładu w rozwój gospodarki danego kraju oraz zdolności do „produkowania siły roboczej” (Gumport, 2000: 73). Z perspektywy ekonomicznej instytucje edukacji wyższej są „otwartymi systemami”, które posiadają określone „zasoby na wejściu” (studenci, profesorowie, środki na badania itd.) i wytwarzają określone „produkty na wyjściu” - usługi, wyniki badań, absolwenci itd. (Valima, 1998: 130). W podobny sposób interpretuje ten problem Anthony R. Welch, pisząc, iż edukacja na poziomie wyższym jest $\mathrm{w}$ coraz większym stopniu oceniana w kategoriach zdolności do produkowania kapitału ludzkiego, udziału w międzynarodowej ekonomicznej konkurencyjności - a nie w kategoriach kształcenia „cywilizowanych” i krytycznie wykształconych obywateli. „Dobro społeczne zastąpione zostało przez dobro ekonomiczne” (Welch, 1997: 229).

W tym świetle wydaje się być zasadne stwierdzenie, że współcześnie mamy do czynienia $\mathrm{w}$ krajach zachodnich $\mathrm{z}$ rosnącą komercjalizacją zarówno uniwersytetów i profesoriatu, jak i dwóch podstawowych funkcji placówek edukacji: badawczej i kształcącej. Występuje więc swoisty paradoks w zakresie „społecznej integracji uniwersytetu" - staje się on, co prawda, stopniowo integralną częścią społeczeństwa, jednak jednocześnie przekształca się - właśnie wskutek tego procesu - ze „świątyni mądrości” w instytucję usługową, w coraz mniejszym stopniu autonomiczną (coś za coś?).

W tym kontekście warto przytoczyć kilka uwag Richarda Wintera, które dobrze wpisują się w powyższe rozważania. Pisze on jednoznacznie: „współczesny 
uniwersytet jest związany w sposób nieunikniony z politycznymi i ekonomicznymi nośnikami kapitalizmu, które kwestionują edukacyjne i akademickie wartości i podporządkowują je formom i priorytetom - zorientowanej na rynek - produkcji” (Winter, 1995: 129). Dla R. Wintera nie ulega wątpliwości, że edukacja wyższa podlega współcześnie intensywnej i bezwzględnej „industrializacji”, która - jak to ujmuje - nie jest bynajmniej konsekwencją dążenia do narzucania jakichkolwiek „dogmatów politycznych”. Stanowi ona (po prostu) wyraz „logiki kapitalizmu”. Przywoływany teoretyk wyprowadza ową logikę z historii nieuchronnych zmian w procesie produkcji i pracy na przestrzeni wieków. Na wstępie przywołuje dawnych rzemieślników, którzy „posiadali unikatową wiedzę”, a także „znali metody i procedury wytwarzania" (niekiedy były one nawet ich tajemnicą). Industrializacja spowodowała narzucenie ścisłej kontroli nad produkcją, a to poprzez kolejne podziały procesu pracy/wytwarzania na coraz prostsze etapy (przy czym żaden pracownik nie posiadał już możliwości objęcia „całego procesu”). Wszelkie decyzje na temat produkcji były podejmowane odgórnie (przez wyspecjalizowanych menedżerów), jej celem nie było już przy tym zaspokajanie ludzkich potrzeb, lecz przynoszenie zysku. Zdaniem R. Wintera, podobnemu procesowi podlega obecnie edukacja wyższa, co wykazuje na przykładzie Wielkiej Brytanii, gdzie rząd narzuca uniwersytetom ideę wykształcenia opartego na kompetencjach definiowanych przez komisje złożone głównie z przedstawicieli wielkich firm i biznesu. Jednocześnie, wiele ważnych inicjatyw w zakresie edukacji wyższej w tym kraju nie ma swojego źródła - jak należałoby oczekiwać - w Ministerstwie Edukacji, lecz w Ministerstwie Pracy, co - jak ujmuje to R. Winter - „oczywiście może służyć jako potwierdzenie najgorszych podejrzeń akademików, że jedynym i to oficjalnym celem edukacji jest przygotowanie siły roboczej". Politycy brytyjscy zresztą nie ukrywają, że celem edukacji wyższej jest "przyczynianie się do wzrostu ekonomicznego poprzez promowanie konkurencyjnego, wydajnego i elastycznego rynku pracy” (Winter, 1995: 130).

Podobna sytuacja występuje w edukacji amerykańskiej. Stała się ona - jak ujmuje to Arthur Levine - w ostatnich dekadach „szybko rozwijającym się przemysłem”, który rząd pragnie „regulować” i „kontrolować”, któremu stawia trudne pytania na temat „kosztów” i „efektywności” (i zarzuca się „niską produktywność”). Rząd „próbuje podejmować decyzje, które kiedyś były wyłączną prerogatywą władz uczelni”. Wywiera też ogromną presję na zwiększenie liczby absolwentów (co postrzegane jest jako synonim postępu) oraz w sferze nauczania, gdzie występuje przejście z - typowej dla przeszłości - orientacji na „proces” na orientację na „rezultaty” (Levine, 1997: 38).

W konsekwencji nauczyciel akademicki przestaje być „mistrzem” czy „mędrcem”, zostaje zredukowany do "tutora” czy wręcz prostego „przekaźnika” (pasa transmisyjnego) pożądanej wiedzy i kompetencji. W takiej sytuacji profesor traci 
kontrolę nad celami, sposobami i ewaluacją kształcenia - wszystko to staje się domeną pracodawcy i ogólnouniwersyteckich (a czasem i zewnętrznych) „procedur jakości kształcenia”. Jednocześnie daleko idąca decentralizacja edukacji akademickiej i przeniesienie punktu ciężkości w zakresie „wyborów” na studentów, konstruujących własne akademickie biografie (co - dodam od siebie - jest bez wątpienia z wielu perspektyw bardzo korzystne), znosi odpowiedzialność profesorów za tożsamość absolwenta. Ich kontakt ze studentem jest coraz bardziej fragmentaryczny; jak pisze R. Winter, akademicy po prostu uprzystępniają studentom „fragment ekspertyzy w ramach skomputeryzowanego systemu opcji” (niczym pracownik na linii produkcyjnej). Typowy dla przeszłości „ogólny autorytet indywidualnego edukatora” przestaje istnieć; profesor jest już jedynie „dostarczycielem towaru w ramach «supermarketu wiedzy», który może, ale nie musi być wybrany przez studenta-klienta”. Główną rolę w takim systemie odgrywać zaczynają „akademiccy menedżerowie", których zadaniem jest optymalne zaprojektowanie całego systemu, oraz „akademiccy doradcy”, którzy kierują („właściwymi”) wyborami studentów. Wszystko to służy rynkowi zgłaszającemu zapotrzebowanie na określony typ absolwenta i jasno precyzującemu swoje żądania w zakresie wiedzy, której produkcji oczekuje od akademików. W ten sposób, jak kontynuuje (w pesymistycznym i przesyconym determinizmem ekonomicznym klimacie) R. Winter, rynek narzuca uniwersytetowi swoje priorytety, a "działania i ludzie są rekonstruowani w kategoriach restryktywnej logiki zysku”. Zgodnie z logiką rynku relacje między nauczycielem, studentem i programem nauczania są przekształcane w relacje między producentem, konsumentem i towarem. Po pierwsze, wiedza jest zapakowana w gotowe i łatwe do przyswojenia „paczki” czy „pigułki”. Po drugie, edukacja wyższa upowszechnia głównie taką wiedzę i kompetencje, które mają wartość rynkową i dzięki temu mogą stać się dla studenta „kredencjałem” (Levine, 1997: 133-136). Uniwersytet więc (powtórzmy raz jeszcze) „sprzedaje” rynkowi grupy absolwentów, którzy zredukowani są do posiadanych przez siebie kwalifikacji.

Przytoczone wyżej poglądy, choć zdają się być skrajne i nazbyt pesymistyczne, nie są niczym niezwykłym we współczesnych dyskusjach na temat społecznej sytuacji uniwersytetu. Oto Sheila Slaughter i Larry L. Leslie w książce zatytułowanej Kapitalizm akademicki eksponują fakt, iż przez całą rewolucję industrialną akademicy w różnych krajach potrafili w znacznym stopniu obronić się przed zasadami gospodarki rynkowej. W zamian za „neutralne” działanie na rzecz dobra publicznego mieli względną niezależność (zarówno od rządów, jak i rynku), nie dążyli do zysku, a ich działania cechował w dużej mierze idealizm. Sytuacja radykalnie zmieniła się w latach osiemdziesiątych XX wieku, kiedy to w większości krajów zakwestionowano wiele z dawnych przywilejów akademickich - profesorowie zaczęli być traktowani jak pracownicy innych sfer, a uniwersytet jak inne przedsiębiorstwa. Wówczas to uniwersytety zostały w bezwzględny sposób włączone w realizację 
„idei rozwoju ekonomicznego", stały się częścią gospodarki rynkowej, a głównym kryterium szacowania ich wartości stała się „konkurencyjność”. W wielu krajach nastąpiło przy tym obcięcie funduszy rządowych, przez co zmuszone były one poszukiwać źródeł finansowania w wielkich korporacjach (Slaughter, Leslie, 1997: 4-5). Trzeba dodać, że skutkiem takiej sytuacji było radykalne zmniejszenie stopnia autonomii edukacji wyższej, sponsorzy mają bowiem zupełnie odmienne - w porównaniu $\mathrm{z}$ tradycją akademicką $\mathrm{w}$ tym zakresie - motywacje, priorytety i oczekiwania wobec badań i ich rezultatów. W konsekwencji próbują oni wpływać zarówno na strukturę i metodologię badań, jak i na interpretację rezultatów oraz sposób ich upowszechniania. Niekiedy przy tym ingerencja taka jest „bardzo inwazyjna" (Tight, 1988: 117); w tym kontekście R. Winter wzywa do powrotu do takiego modelu, $\mathrm{w}$ którym profesor sam w sobie $\mathrm{i}$ jedynie on byłby odpowiedzialny za cały proces badawczy: od wyboru problemów i metod do interpretacji rezultatów (Winter, 1995: 134).

Konkurujące ze sobą o fundusze i granty placówki są zarządzane w coraz większym stopniu w sposób menedżerski. Globalna konkurencja na rynkach światowych spowodowała, iż na przykład w Stanach Zjednoczonych powstały wielkie centra przemysłowo-uniwersyteckie, a działalność edukacji wyższej w Wielkiej Brytanii opiera się w dużej mierze na projektach uniwersytecko-przemysłowo-rządowych. Występuje przy tym radykalny wzrost komercjalizacji badań; S. Slaughter i L.L. Leslie podają w tym kontekście przykład biologii, która jeszcze w dekadzie lat siedemdziesiątych była postrzegana głównie jako nauka podstawowa, a większość badań miało charakter "nie-stosowany”. W ostatnim okresie sytuacja zmieniła się zasadniczo, a to wskutek inwestycji w sektor akademicki wielkich korporacji, poszukujących atrakcyjnych rozwiązań i produktów (Slaughter, Leslie, 1997: 1-2, 6, 8-9, 14-15).

Pisząc o debacie na temat komercjalizacji edukacji wyższej, trudno nie wspomnieć o poglądach Patricii J. Gumport. Utrzymuje ona, iż w ciągu ostatniego ćwierćwiecza nastąpiło stopniowe przekształcenie placówek edukacji wyższej w Stanach Zjednoczonych: $\mathrm{z}$ instytucji o charakterze społecznym w instytucje o charakterze komercyjno-przemysłowym. Wszelkie reformy edukacji wyższej (i kontrola nad jej przebiegiem) mają źródło poza uniwersytetem, a ich inicjatorami są politycy i ekonomiści. Reformy te przebiegają przy tym - zdaniem P. J. Gumport - pod hasłem: „Zwiększyć dostęp, zwiększyć jakość, zmniejszyć koszty” (Gumport, 2000: 68-69). W debatach nad funkcjonowaniem uniwersytetu coraz częściej wykorzystuje się metaforę produkcji oraz konkurencyjności. Imperatywy ekonomiczne zmuszają uczelnie do podejmowania - wyznaczonych przez rynek - krótkoterminowych zadań i celów, zwykle kosztem długoterminowych („pokoleniowych”) interesów nauki i edukacji. Nacisk na efektywność i plastyczność (w reagowaniu na potrzeby zewnętrzne - zwykle ekonomiczno-rynkowe) spowodował erozję funkcji intelektualnych uniwersytetu; w szczególności zakwestionowany został tradycyjny cel, 
jakim było poszukiwanie wiedzy i prawdy. W takiej perspektywie edukację wyższą postrzega się jako przemysł, a uniwersytety jako firmy, których celem jest wytwarzanie i sprzedawanie dóbr i usług, kształcenie siły roboczej, przyczynianie się do rozwoju ekonomicznego, prowadzenie użytkowych badań. Zasady konkurencji rynkowej wymagają optymalnego zarządzania, którego celem jest przekształcenie placówek edukacji wyższej w instytucje wydajne i elastyczne - dla uzyskania maksymalizacji zysków i satysfakcji konsumentów. W takim ujęciu brak sukcesów w dziedzinie adaptacji do zewnętrznych (rynkowych) potrzeb powoduje, iż samo istnienie placówki edukacji wyższej traci sens (Gumport, 2000: 70-71).

Warto w tym miejscu dodać, że - przynajmniej w opinii Gary’ego H. Rhoadesa - w krajach Europy opisywane w tym rozdziale zjawisko ma mniejsze natężenie niż w Stanach Zjednoczonych, bowiem na Starym Kontynencie występuje silne przywiązanie profesorów do „tradycyjnych sposobów działania i funkcji akademickich". Zdaniem tego autora w wielu przypadkach europejscy profesorowie przeciwstawiali się tym wysiłkom rządowym, które skierowane były na reorganizację programów nauczania - tak, aby w większym stopniu odpowiadały one obecnemu rynkowi pracy. Wysiłki te określano pejoratywnie mianem „uzawodowienia” (vocationalization). „Jako całość europejscy akademicy są [...] konserwatywni w sferze eksperymentów dokonywanych na programach [...] i aktywnie opierają się im poprzez pewne profesjonalne mechanizmy samoregulacji”. Jednocześnie, według G.H. Rhoadesa, kryteria przyjmowane przez akademików (w Europie) do ewaluowania własnej pracy nie uwzględniają ani „reaktywności na rynek”, ani innych i „pozaakademickich presji” (Rhoades, 1987: 14). Wydaje się - analizując sytuację choćby w Wielkiej Brytanii - że tego typu optymistyczne wnioski nie do końca są uzasadnione.

Krytycy eksponują inną jeszcze konsekwencję komercjalizacji uniwersytetów. Związana jest ona $\mathrm{z}$ upadkiem znaczenia badań podstawowych w porównaniu ze stosowanymi, jak również z rosnącą rywalizacją poszczególnych dyscyplin naukowych o zewnętrzne fundusze. Jak pisze Brian Martin, w przeszłości istniało przekonanie, że badania podstawowe są bardziej prestiżowe niż stosowane. Te pierwsze miały „symbolizować niezależność [uniwersytetu] od czynników zewnętrznych”, te drugie natomiast są rezultatem nieuchronnego kompromisu między zainteresowaniami akademika a zapotrzebowaniem zgłaszanym ze strony różnych grup społecznych (Martin, 2012). W przeszłości „akademickim dogmatem było przekonanie, że misją Akademii jest poszukiwanie wiedzy - jako cel sam w sobie”. „Pozycja uniwersytetu i pozycja partykularnego badacza nie była [...] determinowana przez bezpośrednią użyteczność uzyskiwanych wyników badań, lecz przez wkład w zrozumienie ludzkości i natury oraz uzyskanie prawdy o nich" (Brown, Clignet, 2000: 38). Współcześnie sytuacja w tym zakresie zmieniła się zasadniczo - na korzyść nauk stosowanych, a to z uwagi na fakt, iż to one właśnie w większym stopniu 
przyczyniają się do rozwoju ekonomicznego (Tight, 1988: 117). Jak piszą w tym kontekście R.H. Brown i R. Clignet, „krótkoterminowe presje na uniwersytet spowodowały upadek badań podstawowych - na rzecz stosowanych" (Brown, Clignet, 2000: 38).

Jednocześnie w sytuacji, gdy każda dyscyplina (czy wydział na uniwersytecie) wychodzi „na rynek z własną ofertą”, a „oferta wydziałów humanistycznych jest mniej konkurencyjna”, „następuje upadek znaczenia tych nauk” (Wolfe, 1996: 1, 3-5, 6). Badania amerykańskie wykazują, że w ostatnim okresie nastąpiła zmiana parytetów w zakresie finansowania poszczególnych dyscyplin zarówno ze strony rządów, jak i władz poszczególnych uniwersytetów. Owo przemieszczenie środków wynikało z bezwzględnego oszacowania ich „potencjalnej konkurencyjności”; w ten sposób zyskały - jak piszą S. Slaughter i L.L. Leslie - niektóre subdyscypliny nauk ścisłych, biologicznych i chemicznych, zarządzanie i prawo, z kolei nauki humanistyczne i społeczne utraciły fundusze (Slaughter, Leslie, 1997: 1-15).

W tym kontekście Jon Huer pisze ironicznie (jednak w tonacji niepozbawionej uzasadnionego dramatyzmu), iż w sytuacji ograniczenia finansowania nauk, które wytwarzają wiedzę „społecznie bezużyteczną”, narasta groźba zakwestionowania ich istnienia samego w sobie. Widzi on na przykład możliwość „całkowitego zniknięcia socjologii i filozofii - jako pozostających w opozycji do chemii lub księgowości”. „Nie spowoduje to w praktyce żadnych społecznych konsekwencji z wyjątkiem tych, które bezpośrednio dotkną filozofów i socjologów samych w sobie" (Huer, 1991: 13); kogo bowiem obchodzi dzisiaj sens życia i wszechświata? Podobne stanowisko zajmuje A.R. Welch, omawiający sytuację w szkolnictwie wyższym w Wielkiej Brytanii, który twierdzi, iż w kraju tym „występuje rosnące zagrożenie dla akademików z nauk społecznych i humanistycznych, którzy (w przeciwieństwie do tych np. z zarządzania) nie mają możliwości kumulowania zysku" - więcej nawet - istnieje wręcz egzystencjalne zagrożenie dla „katedr, wydziałów, a nawet całych uniwersytetów, które mają trudności w sferze urzeczywistniania kryteriów ekonomicznej użyteczności” (Welch, 1997: 300).

Opisane powyżej zmiany funkcji uniwersytetów następują poprzez trojakiego rodzaju mechanizmy:

1. Akademicki menedżeryzm. Polega on na wspomnianej już zmianie w stylu kierowania uniwersytetem: coraz mniejszą rolę odrywają profesorowie/intelektualiści, coraz większą typowi menedżerowie, którzy - nie mając z nauką i nauczaniem nic wspólnego - wyznaczają jednak tym pierwszym cele i zadania, rozważają „aktywa” i „pasywa”, przewidują „koszty” i „korzyści”, zwiększają efektywność i plastyczność, „określają warunki”, „korygują niedostosowania”. Uważają oni, iż przetrwanie uniwersytetu jako instytucji zależy od jego zdolności do udzielenia optymalnych odpowiedzi na dynamiczne (zmienne) bodźce środowiskowe. Celem menedżerów staje się „monitorowanie” relacji między uniwersytetem a środowi- 
skiem zewnętrznym oraz kształtowanie organizacyjnej plastyczności uniwersytetu, tak, aby nie wypadł on z „gry” w sytuacji zmiany warunków (oczekiwań), a także wytwarzanie takiego „produktu edukacyjnego”, który może być sprzedany po jak najwyższej cenie. Profesorowie, badacze i nauczyciele akademiccy są postrzegani przez menedżerów w kategoriach „kalkulatywnych” (wyłącznie jako wydajni pracownicy): uważa się, że można ich „motywować” poprzez bodźce i sankcje (Gumport, 2000: 72-73, 76).

2. Akademicki konsumeryzm. Zasada racjonalności ekonomicznej, według której powinien funkcjonować współczesny uniwersytet, ma ogromny wpływ na jego życie codzienne. Oto bowiem dyplomy akademickie, kursy i kredyty nie posiadają już wartości same w sobie, jako symbole wiedzy i wykształcenia; są one po prostu sprzedawane tak, jak każdy inny towar. Akademickie usługi w sferze kształcenia/ nauczania oraz wytwarzania wiedzy są określone poprzez relacje popytu i podaży, a studenci i ich rodzice, administracja lokalna i rządowa, jak również placówki składające zamówienia na określone badania są traktowani wyłącznie jako klienci/konsumenci (którzy - jak ujmuje to G. Rhoades - „mają zarówno prawo do żądania określonych produktów i wyboru spośród nich, jak i mają prawo ewaluowania producenta" (Rhoades, 1987: 9). Edukacja wyższa nie jest postrzegana w kategoriach „intelektualnych”, lecz „użytkowych”. P.J. Gumport stwierdza ironiczne: „zakup usług edukacyjnych odbywa się na takich samych zasadach jak zakup samochodu". Sami studenci nie traktują już swojego pobytu na uniwersytecie w kategoriach przynależności do społeczności akademickiej, lecz coraz częściej jak pobyt w ogromnym domu towarowym. Istotą studiów i studiowania nie jest już dążenie do rozwoju osobowości, zdobycia wiedzy, rozszerzenia horyzontów intelektualnych czy nawiązywania całożyciowych przyjaźni. Pobyt na uniwersytecie nabiera charakteru „akademickiej transakcji businessowej” - w której to niemal wyłącznie oczekiwania studenta/konsumenta w zakresie uzyskiwania usług edukacyjnych oraz prawa rynku wyznaczają zakres przekazywanej wiedzy i kwalifikacji. Dodam od siebie, że w przeszłości struktura programów nauczania i zakres wiedzy oraz kompetencji wynikały zwykle z (arbitralnie narzucanych) kryteriów „profesorskich” - to akademicy określali, co jest częścią „kanonu”, co powinien wiedzieć i umieć absolwent, aby mógł być uznany za człowieka wykształconego. Dziś wiedza akademicka coraz częściej jest dzielona na „użyteczną” (którą można wykorzystać na rynku pracy) i „zbyteczną" (zwykle „ogólną”, która nie może być wykorzystana w praktyce zawodowej). W ten sposób - aby powrócić do rozważań P.J. Gumport - to gust konsumenta i oczekiwania rynku pracy decydują o programach nauczania, kursach i profilu absolwenta. Ponieważ jednak owe „zewnętrzne” czynniki są zmienne, uniwersytet funkcjonuje w warunkach „niestabilności”, w konsekwencji dąży do pozostawania w stanie nieustannej gotowości do natychmiastowej reakcji na nowe oczekiwania, działa „krótkoterminowo”. Nieodwracal- 
nym zjawiskiem jest tu jednak utrata znaczenia przez dawne akademickie tradycje i idee (Gumport, 2000). W takiej sytuacji przestają być istotne takie tradycyjne (społeczne) funkcje uniwersytetów, jakimi w przeszłości były: kultywowanie tradycji edukacyjnych, zachowanie dziedzictwa kulturowego, kształtowanie tożsamości jednostek (postaw obywatelskich, charakterów i umysłów), orientacja na wiedzę jako wartość samą w sobie. W konkluzji P.J. Gumport stwierdza z pełnym przekonaniem: funkcja ekonomiczna uniwersytetu z powodzeniem wypiera jego funkcję socjalizacyjną (Gumport, 2000: 75).

3. Akademicka re-stratyfikacja. W nowych warunkach funkcjonowania uniwersytetów zachwiana zostaje dawna „hierarchia akademicka”. Nowym kryterium szacowania przedmiotów i kursów, zakładów, katedr i wydziałów, a także poszczególnych osób („personelu akademickiego”) staje się „wartość użytkowa i rynkowa wartość wymienna partykularnych form wiedzy, którą są oni w stanie wytworzyć" (Gumport, 2000: 81).

W kontekście omówionych wyżej zjawisk i procesów J. Enders wyróżnia cztery możliwe scenariusze przyszłości „profesoriatu”. Pierwszy scenariusz jest optymistyczny (dodam, iż jest on mało prawdopodobny, ponieważ wymaga odwrócenia istniejących inwazyjnych trendów). Zakłada on, iż typowa dla współczesnego społeczeństwa orientacja na naukę zwiększy znaczenie profesji akademickiej, która nie tylko będzie źródłem wiedzy i kompetencji, ale także będzie służyć jako „model dla racjonalnego i obiektywnego dyskursu na rzecz ekspertyz o wysokiej jakości”. Akademików postrzega się w tym kontekście jako źródło profesjonalnego kształcenia, socjalizowania i selekcjonowania innych profesjonalistów jako ekspertów i wytwórców wiedzy.

Drugi scenariusz jest pesymistyczny. Oto bowiem profesja akademicka utraci swoją kluczową pozycję (w zakresie przywilejów i władzy) i to nawet na płaszczyźnie edukacji wyższej samej w sobie - na rzecz menedżerów, innych instytucji społecznych i rządów państw. Różnorodne „zewnętrzne presje” doprowadzą do „deprofesjonalizacji”, „biurokratyzacji” i „marginalizacji” profesorów. Nastąpi upadek tradycyjnego profesoriatu, wystąpi też zjawisko „rozczarowania akademików swoją własną misją", a także rezygnacja z tradycyjnych wartości i norm, które cechowały profesję akademicką. W tym przypadku akademicy będą postrzegani jedynie jako „instytucjonalne źródło, dostarczające mniej lub bardziej efektywne usługi”.

Scenariusz trzeci („katastroficzny”) zakłada rosnącą marginalizację uniwersytetu jako instytucji społecznej. Profesorowie staną się , antykami”, a inne instytucje będą lepiej (niż edukacja wyższa) służyć tym podstawowym potrzebom społecznym, jakimi są: wytwarzanie nowej wiedzy i kształcenie młodej generacji.

Wreszcie scenariusz czwarty przewiduje, iż tradycyjny typ uniwersytetu zostanie przekształcony zgodnie $\mathrm{z}$ wymogami postindustrialnego czy postmodernistycznego społeczeństwa. Dawne funkcje pełnione przez akademików staną się 
przestarzałe. Akademicy przestaną funkcjonować jako „legislatorzy tradycyjnej akademickiej kultury i wiedzy", ograniczą się do interpretowania prawdy jako pojęcia relatywnego. Badania będą organizowane w sposób niehierarchiczny, pluralistyczny, transdyscyplinarny, będą stanowiły reakcje na „impulsy społeczne”. Kluczowymi pojęciami staną się w tym kontekście: relatywizm, multiprofesjonalizm, plastyczność, wystąpi też erozja tradycyjnej autorytatywnej wiedzy („scenariusz ten niektórzy z nas witają z entuzjazmem, inni postrzegają jako "zmorę nocną»"; Gumport, 2000: 75-76). I wydaje mi się, że ten scenariusz jest najbardziej prawdopodobny.

\section{Literatura}

Altbach P.G. (1997). The International Academic Crisis? The American Professoriate in Comparative Perspective. "Daedalus" Fall, vol. 126, no 4

Brown R.H., Clignet R. (2000). Democracy and Capitalism in the Academy: the Commercialization of American Higher Education. [In:] Knowledge and Power in Higher Education. Ed. R.H. Brown, J.D. Schubert. New York-London

Gumport P.J. (2000). Academic Restructuring: Organizational Change and Institutional Imperatives. "Higher Education" vol. 39

Huer J. (1991). Tenure for Socrates. New York

Kivinen O. (1997). Graduate Credentials in a Changing Labour Market. "Higher Education in Europe" vol. 22, no 4

Kivinen O., Ahola S. (1999). Higher Education as Human Risk Capital. "Higher Education" vol. 48

Kwieciński Z. (2000). Tropy - ślady - próby. Szkice z pedagogiki pogranicza. Poznań-Olsztyn

Levine A. (1997). How the Academic Profession is Changing. "Daedalus. Journal of the American Academy of Arts and Sciences" Fall

Martin B. (2012). Tied Knowledge: Power in Higher Education, http://www.uow.edu.au/arts/sts/ bmartin/pubs/98tk/ (dostęp 31.07.2012)

Melosik Z. (2000). Uniwersytet a przemiany kultury współczesnej. "Studia Edukacyjne” vol. 5

Rhoades G. (1987). Higher Education in a Consumer Society. "Journal of Higher Education" vol. 1 Slaughter S., Leslie L.L. (1997). Academic Capitalism. Politics, Policies and the Entrepreneurial University. Baltimore and London

Tight M. (1988). So, What is Academic Freedom. [In:] Academic Freedom and Responsibility. Ed. M. Tight. Stratford

Valima J. (1998). Culture and Identity in Higher Education Research. "Higher Education" vol. 35 Welch A.R. (1997). All Change? The Professoriate in Uncertain Times. "Higher Education" vol. 34 Winter R. (1995). The University of Life plc: the "Industrialization" of Higher Education? [In:] Academic Work. Ed. J. Smyth. Buckingham

Wolfe A. (1996). The Feudal Culture of the Postmodern University. “The Wilson Quarterly” vol. 1 


\title{
University and Commercialization. Reconstruction of the Western Debate
}

\author{
Summary
}

In his article Zbyszko Melosik focuses on the problem of the commercialization of university. He points out that university has become one of many social institutions and its work is regarded in terms of providing "services" and "products". He writes that the idea of "knowledge for knowledge's sake" has been replaced by the idea of "useful knowledge". The idea of a bright, smart, intelligent graduate has been replaced by the model of a "specialized pragmatist", who is able to find a job easily and will be boosting economic "prosperity instead". Z. Melosik argues that the market is provided with graduates in ready-made packages and the students themselves want to get knowledge and skills that help them to fit into the job market. Their life orientation is directed towards success and the approach of "to have" not "to be". The author of the article refers to the situation in the United States and the United Kingdom, and shows that higher education is run exactly like corporations and government. Z. Melosik refers to the words of A. Levine who writes that American education has become a fast developing industry in recent decades. The government wants to regulate and control it especially when it comes to costs and efficacy (and accuses universities of low-productivity). Government "makes an attempt to take decisions which have always been university boards' prerogatives". It puts pressure on universities in the field of increasing the role of the student body (which is regarded as progress) and also in the field of teaching, where one can observe the shift from classical orientation on 'process' to the current orientation on 'results'. As a consequence of this approach, the academic is not a 'master' or 'sage' anymore, he or she is reduced to the 'tutor' or even to a simple 'knowledge transmitter' (a transmission belt) of the desirable knowledge and competences. "General authority of an individual educator" characteristic of the past does not exist anymore; a professor is only "a goods provider in terms of knowledge shopping mall, which can but not have to be chosen by the student-customer". Academic managers who are in charge of planning the whole system and academic counselors who are responsible for the (appropriate) student choices play the leading role in that system. This system serves the market, which demands a specified model of a graduate and clearly specifies its skills requirements which are expected to be produced by the academics. The relations between academics, students and the curriculum are reconstructed according to the logics of the market and the relations between producer, customer and the good. Melosik states that it is worth noticing that a consequence of the mentioned situation there was a dramatic reduction of the autonomy of higher education. The sponsors have totally different motivations, priorities and expectations - in comparison to the traditional university approach - toward research and its results.

The author of the article refers to the opinion of Patricia J. Gumport. He writes that any higher education reforms (and control over them) stem from outside the university with politicians and economists as the initiators. The pressure on efficacy and flexibility corroded the intellectual functions of the university. The traditional function of the university, searching for truth and knowledge, was especially questioned. In that perspective, higher education is regarded as an industry and universities as companies are aimed to produce goods and services, an educated work force, to boost the economy, and to carry on useful research. Z. Melosik also focuses on the problem of decreasing the significance of pure science in comparison to applied science and also on increasing competition between particular disciplines in chase of external 
funds. In a situation where every discipline (or school at university) enters the market with an individual offer, and the offer of humanities is less competitive, the significance of the latter decreases.

In the next part of his article the author describes three types of mechanisms that appear at universities in reaction to commercialization:

Academic managerialism - academic staff play a less important role than typical managers, who do not have any connections with science and education, but they set the goals and tasks, consider "assets" and "liabilities", foresee "costs" and "benefits", and decrease efficacy and flexibility.

Academic consumerism - the rationality principle has a great influence on university functions. Credentials, courses and credits are no longer valued as symbols of knowledge and education; instead they are just sold like any other good.

Academic re-stratification - a new criteria of evaluating courses, schools, departments and academic staff is applied as a value and the market value of particular forms of knowledge they are able to produce.

At the end of the article, Zbyszko Melosik refers to J. Enders who distinguishes four possible scenarios for the future of professoriate. The last of them assumes the traditional model of university to be transformed according to the rules of postindustrial and postmodern society. The academic staff will not continue as legislators of traditional academic culture and knowledge, they will limit themselves to interpreting truth as a relative notion. The research will be organized in a non-hierarchical, pluralistic, trans-disciplinary way and will react to 'social impulses'. Relativism, multi-professionalism and plasticity will become the key-concepts. Moreover the erosion of traditional, authoritarian knowledge will appear. The author states that this scenario is the most likely to come true. 
